\title{
Kecepatan Aliran Darah pada Arteri Abdominalis Berdasarkan Indeks Massa Tubuh Terhadap Pasien Hipertensi di Rumah Sakit Umum Anutapura Kota Palu
}

\author{
Nurul Fadila ${ }^{1}$, Kasman $^{1}$, Syahrul Ulum ${ }^{1}$ \\ ${ }^{1}$ Jurusan Fisika Fakultas Matematika dan Ilmu Pengetahuan Alam Universitas Tadulako \\ Email:nurulfadila961@gmail.com
}

\begin{abstract}
ABSTRAK
Telah dilakukan penelitian penelitian tentang kecepatan aliran darah pada arteri abdominalis berdasarkan indeks massa tubuh (IMT) terhadap pasien hipertensi di RSU Anutapura Palu. Tujuan dari penelitian ini adalah untuk mengetahui hubungan antara IMT terhadap kecepatan aliran darah pada pasien yang mengidap hipertensi. Data tinggi badan dan berat badan yang masing-masing diukur dengan stature meter dan alat timbangan berat badan untum perhitungan IMT sedang pengukuran kecepatan aliran darah menggunakan Ultrasonografi Doppler. Pada penelitian ini jumlah pasien hipertensi sebanyak 52 orang (29 - 58 tahun) dengan kategori IMT yaitu kurus, normal, gemuk dan obesitas. Berdasarkan uji statistic, tidak terdapat korelasi antara IMT dengan kecepatan aliran darah. Adapun distribusi pasien berdasarkan IMT dan kecepatan aliran darah didominasi oleh kategori kecepatan lambat dengan persentasi masing-masing untuk kurus $23,077 \%$, normal $19,231 \%$, gemuk $25,000 \%$ dan obesitas $23,077 \%$.
\end{abstract}

Kata kunci: Hipertensi, IMT, kecepatan aliran darah, dan ultrasonografi doppler

\begin{abstract}
Research has been conducted on the speed of blood flow in the abdominal arteries based on body mass index (BMI) in hypertensive patients at Anutapura Hospital in Palu. The purpose of this study is to determine the relationship between BMI to the speed of blood flow in hypertension patient's abdominal arteries. For the assessment of BMI, height and weight measurements were carried out using stature meter and portable spring weighting machine, respective was measuring blood flow velocity using Doppler Ultrasonography. In this study the number of hypertensive patients was 52 people (29 - 58 years) with BMI categories namely underweight, normal, overweight and obese. The relationship between BMI and the level of blood flow can be seen using the Statistical Test, which results show that there is no correlation between them. The distribution of patients based on BMI and speed of blood flow was dominated by slow speed categories with a percentage of each for underweight $23.077 \%$, normal $19.231 \%$, overweight $25,000 \%$ and obesity $23,077 \%$.
\end{abstract}

Keywords: Hypertension, BMI, speed of blood flow, and doppler ultrasonography 


\section{PENDAhuluan}

Hipertensi adalah suatu keadaan tekanan sistolik seseorang adalah lebih atau sama dengan $140 \mathrm{mmHg}$ dengan tekanan diastolik lebih atau sama dengan $90 \mathrm{mmHg}$ (Ardiansyah, 2012). Hipertensi dapat disebabkan oleh berbagai faktor diantaranya merokok, konsumsi garam, kebiasaan minumminuman beralkohol, stres dan kegemukan (Kemenkes RI, 2013).

Kegemukan merupakan salah satu faktor utama (bersifat fleksibel) yang mempengaruhi tekanan darah dan juga perkembangan hipertensi. Saat ini diperkirakan jumlah orang di seluruh dunia dengan IMT > 30 melebihi 250 juta orang, yaitu sekitar 7\% dari populasi orang dewasa di dunia (Sugondo, 2009). Di Amerika Serikat, 55\% populasi mengalami kelebihan berat badan dan 22\% diantaranya obesitas (Ganong, 2008). Menurut data riset kesehatan Republik Indonesia dasar tahun 2013, provinsi Sulawesi Tengah termasuk ke dalam 10 besar provinsi dengan penyakit hipertensi menempati peringkat ke-6 dengan total kasus sebanyak 28,7\%. Data rekam medik di Rumah Sakit Umum Daerah Undata Palu, menunjukkan bahwa mulai dari tahun 2012 penderita penyakit hipertensi rawat jalan sebanyak 1.078 pasien, mengalami peningkatan pada tahun 2013 dengan penderita sebanyak 1.123 pasien (Niken Wike Wijayanti dkk, 2016).

Banyak penyelidikan membuktikan adanya hubungan antara IMT dengan kejadian hipertensi dan diduga peningkataan berat badan memiliki peranan penting pada mekanisme timbulnya hipertensi. Penyumbatan dan penyempitan memacu jantung untuk memompa darah lebih kuat lagi agar dapat memasok kebutuhan darah ke jaringan. Akibatnya tekanan darah meningkat maka akan terjadi hipertensi (Moudy, 2014).

Beberapa penelitian sebelumnya yang telah dilakukan untuk menghitung kecepatan aliran darah pada pembuluh darah yang berbeda, Samad (2012) mengukur kecepatan aliran darah pada aorta abdominalis pasien non hipertensi dan hipertensi dengan kecepatan masing-masing $227 \mathrm{~mm} / \mathrm{s}$ dan $135 \mathrm{~mm} / \mathrm{s}$. Selain itu, Hardiyan (2013) telah mengukur kecepatan aliran darah pada arteri karotis diperoleh kecepatan aliran darah $595 \mathrm{~mm} / \mathrm{s}$ untuk pasien non hipertensi dan pada pasien hipertensi kecepatan aliran darah sebesar 252 $\mathrm{mm} / \mathrm{s}$.

Berdasarkan uraian diatas, maka perlu dilakukan penelitian untuk mengetahui pengaruh Indeks Massa Tubuh (IMT) terhadap kecepatan aliran darah pada arteri abdominalis pasien hipertensi.

\section{METODE PENELITIAN}

Pada penelitian ini, menghitung IMT dengan mengukur berat badan dan tinggi badap pasien, sementara pengukuran kecepatan aliran darah $(\mathrm{Vm})$ menggunakan USG Doppler, selanjutnya data akan dianalisis menggunakan uji Chi Square dan Uji Korelasi Spearmen. Kedua uji tersebut bertujuan untuk mengetahui seberapa besar hubungan antara kedua variabel. Adapun langkah-langkah dari uji Chi Square dan Uji Korelasi adalah sebagai berikut:

1) Menentukan Hipotesis

Hipotesis yang digunakan dalam uji statistik metode Chi Square adalah sebagai berikut: 
a. $\mathrm{H}_{0}$ (Hipotesa awal): Tidak tererdapat hubungan antara IMT dengan kecepatan aliran darah.

b. $\mathrm{H}_{\mathrm{a}}$ (Hipotesa alternatif): Terdapat hubungan antara IMT dengan kecepatan aliran darah.

2) Menentukan tingkat signifikasi a yaitu sebesar $5 \%$ atau 0,05 .
3) Menentukan nilai derajat kebebasan $(\mathrm{db}=$ $\mathrm{K}-1$ ), kemudian menentuan nilai $X_{\text {tabel }}^{2}$ yang didapatkan melalui tabel statistik $X^{2}$.

4) Kriteria pengujian: Jika $\chi_{\text {hitung }}^{2}<\chi_{\text {tabel }}^{2}$ maka $\mathrm{H}_{\mathrm{o}}$ diterima.

Uji Korelasi, menentukan tingkat signifikasi $\alpha$ yaitu sebesar 5\% atau 0,05.

\section{HASIL DAN PEMBAHASAN}

Tabel 1. Distribusi pasien berdasarkan usia dan kategori IMT

\begin{tabular}{ccccccccc}
\hline & \multicolumn{7}{c}{ Kategori Indeks Massa Tubuh (IMT) } \\
\cline { 2 - 9 } $\begin{array}{c}\text { Usia } \\
\text { (thn) }\end{array}$ & $\begin{array}{c}\text { Kurus } \\
\text { (org) }\end{array}$ & $\%$ & $\begin{array}{c}\text { Normal } \\
\text { (org) }\end{array}$ & $\begin{array}{c}\text { Gemuk } \\
\text { (org) }\end{array}$ & \multicolumn{2}{c}{$\begin{array}{c}\text { Obesitas } \\
\text { (org) }\end{array}$} & $\%$ \\
\hline $29-38$ & 8 & 15,384 & 4 & 7,692 & 1 & 1,923 & 2 & 3,846 \\
$39-48$ & 5 & 9,615 & 6 & 11,538 & 9 & 17,308 & 6 & 11,538 \\
$49-58$ & 0 & 0,000 & 3 & 5,769 & 3 & 5,769 & 5 & 9,615 \\
\hline
\end{tabular}

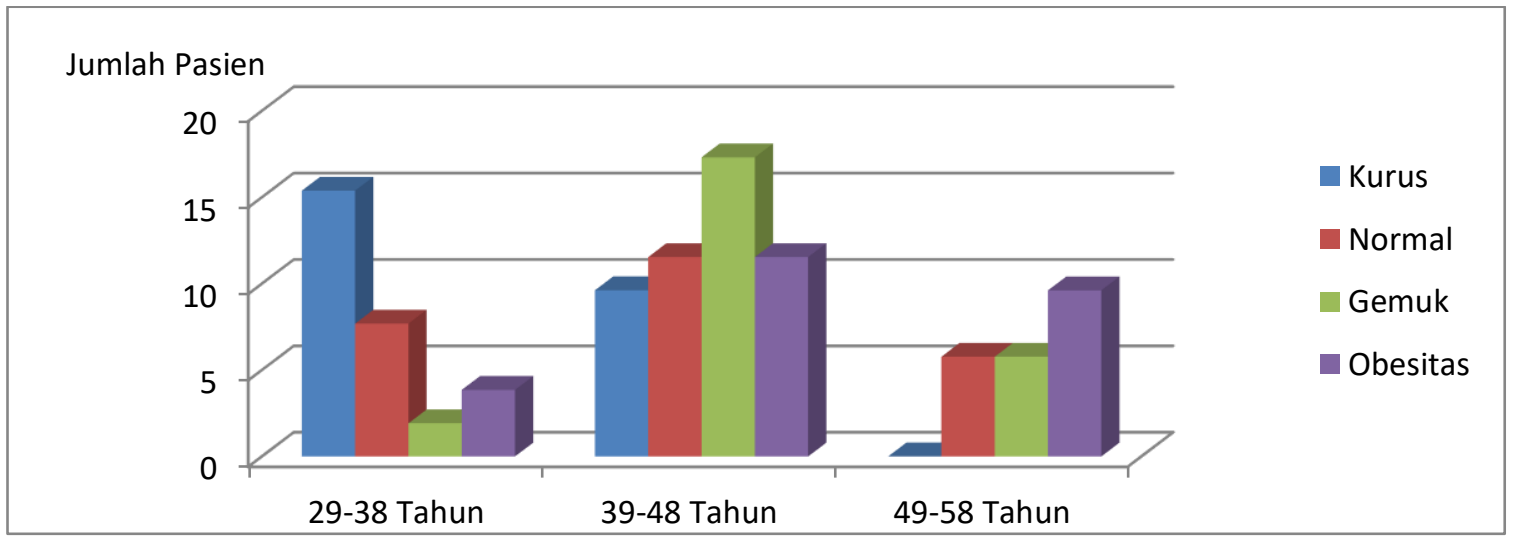

Gambar 1. Distribusi pasien berdasarkan usia dan kategori IMT

Berdasarkan Tabel 1 hubungan antara usia dan kategori IMT pada uusia 29-38 tahun lebih dominan kategori kurus, hal ini bisa saja dipengaruhi oleh asupan gizi dan pada usia ini merupakan masa lebih aktif dalam melakukan aktifitas. Selanjutnya pada usia 39-48 tahun didominasi oleh kategori gemuk yang mana pada usia ini dapat dikatakan sebagai usia matang dimana lebih fokus terhadap pekerjaan sehingga tidak memperhatikan diri sendiri, salah satu faktor yang mempengaruhi yaitu makanan tidak sehat seperti makanan siap saji sehingga mempengaruhi kesehatan. Untuk rentan usia 49-58 didominasi oleh 
kategori obesitas yang mana pada usia ini dipengaruhi oleh kurangnya aktivitas fisik, selain itu juga diakibatkan daya tahan tubuh menurun atau rentang terhadap penyakit.

Berdasarkan Gambar 1 hubungan antara usia dan kategori IMT diperoleh bahwa pada usia 29-38 tahun jumlah persentasi terbanyak terdapat pada kategori kurus dengan persentase $15,384 \%$, untuk usia 39-48 tahun dengan persentase $17,308 \%$ pada kategori gemuk, dan usia 49-58 tahun pada kategori obesitas dengan persentase 9,615\%. Pada lampiran 1 juga tampak bahwa besarnya nilai kecepatan aliran darah rata-rata pasien di RSU Anutapura memiliki perbedaan dengan nilai $\mathrm{Vm}$ antara 135,7 - 229,7 $\mathrm{mm} / \mathrm{s}$.

Tabel 2. Distribusi sampel berdasarkan usia dan kecepatan aliran darah

\begin{tabular}{rcccccc}
\hline & \multicolumn{6}{c}{ Kecepatan Aliran Darah ( mm/s) } \\
\cline { 2 - 7 } $\begin{array}{r}\text { Usia } \\
\text { (thn) }\end{array}$ & $\begin{array}{c}\text { Lambat } \\
\text { (org) }\end{array}$ & $\%$ & $\begin{array}{c}\text { Sedang } \\
\text { (org) }\end{array}$ & $\%$ & $\begin{array}{c}\text { Cepat } \\
\text { (org) }\end{array}$ & $\%$ \\
\hline $29-38$ & 12 & 23,077 & 2 & 3,846 & 1 & 1,923 \\
$39-48$ & 15 & 28,846 & 1 & 1,923 & 0 & 0 \\
$49-58$ & 20 & 38,461 & 0 & 0 & 1 & 1,923 \\
\hline
\end{tabular}

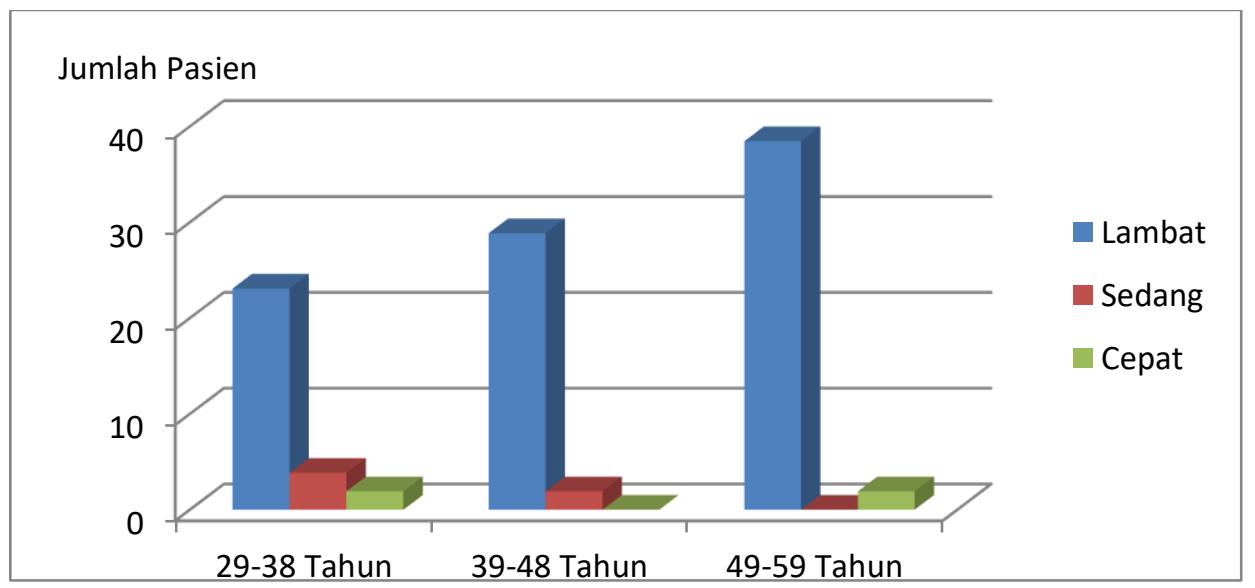

Gambar 2. Distribusi sampel berdasarkan usia dan kecepatan aliran darah

Berdasarkan data pada Gambar 2 hubungan antara usia dengan kecepatan aliran darah didominasi dengan kategori kecepatan aliran darah lambat, pada usia 29-38 tahun dengan persentase $23,077 \%$. Untuk usia 39-48 tahun dengan persentase $28,846 \%$, dan untuk usia
49-58 tahun dengan jumlah persentase terbanyak yaitu $38,461 \%$. Selain itu, berdasarkan lampiran 1 dapat diidentifikasi bahwa pasien hipertensi yang termasuk dalam kategori hipertensi derajat I untuk usia 29-38 tahun sebesar $15,384 \%$, usia $39-48$ tahun 
sebanyak 30,769\%, dan usia 49-58 tahun sebanyak 7,692\%. Selanjutnya untuk hipertensi derajat II pada usia 29-38 ahun sebesar $13,461 \%$, usia 39-49 tahun sebesar $19,231 \%$ dan usia 49-58 tahun sebesar $13,461 \%$. sebanyak $57,69 \%$.

Berdasarkan data pada Tabel 2 hubungan antara usia dengan kecepatan aliran darah, pada diagram dapat dilihat objek penelitian didominasi oleh pasien hipertensi dengan kategori kecepatan aliran darah lambat yang semakin meningkat seiring dengan bertambahnya usia. Hal ini didasari oleh penelitian sebelumnya menjelaskan bahwa persentase semakin bertingkat sesuai umur hal ini dikarenakan tekanan darah pada usia lanjut (lansia) akan cenderung tinggi sehingga lansia lebih besar berisiko terkena hipertensi (tekanan darah tinggi). Bertambahnya umur mengakibatkan tekanan darah meningkat, karena dinding arteri pada usia lanjut (lansia) akan mengalami penebalan yang mengakibatkan penumpukan zat kolagen pada lapisan otot, sehingga pembuluh darah akan berangsur-angsur menyempit dan menjadi kaku (Anggraini dkk, 2009). Penelitian lain (Pearce, 2008) yang menyatakan bahwa kecepatan aliran darah berbanding terbalik tekanan darah pasien dimana apabila tekanan darah naik maka kecepatan darah akan menurun demikian sebaliknya. Sebagai contoh, pada tekanan darah sistolik 140/90 mmHg (K2) mempunyai kecepatan aliran darah rata-rata $217 \mathrm{~mm} / \mathrm{s}$, sedangkan pada tekanan darah 170/100 $\mathrm{mmHg} \quad$ (O13) mempunyai kecepatan aliran darah rata-rata $166,33 \mathrm{~mm} / \mathrm{s}$, yang mana pada penelitian ini pasien yang bertekanan darah tinggi dengan kecepatan aliran darah kurang dari 200 mm/s.

Tabel 3. Hubungan antara IMT dengan kecepatan aliran darah

\begin{tabular}{ccccccc|c|c|c|}
\hline \multirow{2}{*}{$\begin{array}{c}\text { Kategori } \\
\text { IMT }\end{array}$} & $\begin{array}{c}\text { Lambat } \\
\text { (org) }\end{array}$ & $\%$ & $\begin{array}{c}\text { Sedang } \\
(\text { org })\end{array}$ & $\%$ & Cepat & $\%$ & Normalisasi & Uji Chi & Uji \\
Square & (org) & & $(\mathrm{P})$ & $\begin{array}{c}\text { Korelasi } \\
\left(\mathrm{X}^{2}\right)\end{array}$ & $(\mathrm{r})$ \\
\hline Kurus & 12 & 23,077 & 1 & 1,923 & 0 & 0 & & & \\
Normal & 10 & 19,231 & 1 & 1,923 & 2 & 3,846 & & & \\
Gemuk & 13 & 25,000 & 0 & 0 & 0 & 0 & 0,640 & 14,231 & $-0,074$ \\
Obesitas & 12 & 23,077 & 1 & 1,923 & 0 & 0 & & & \\
\hline
\end{tabular}

Berdasarkan Tabel 3 di peroleh nilai signifikansi uji Normalitas kedua data yaitu sebesar 0,640. Adapun syarat data dikatakan normal yaitu apabila nilai signifikan > 0,05, maka berdasarkan nilai signifikan yang diperoleh dapat dinyatakan bahwa data tersebut berdistribusi normal, karena nilai signifikan > 0,05 $(0,640>0,05)$. Selanjutnya apabila kedua data telah berdistribusi normal maka langkah berikutnya adalah melakukan Uji Chi Square antara kedua data sehingga hasil penelitian dengan derajat bebas 41 dan taraf signifikansi $5 \%$ di peroleh nilai $x^{2}$ hitung sebesar 14,231 lebih kecil dari nilai $\mathrm{X}^{2}$ tabel 56,94 dengan demikian $\mathrm{H}_{\mathrm{o}}$ diterima yang berarti terdapat hubungan antara IMT dengan kecepatan aliran darah. Selanjutnya untuk mengambil keputusan adanya korelasi 
antara kedua variable tersebut maka perlu dilakukan pengujian korelasi Spearmen terhadap kekuatan dan nilai signifikansi korelasi tersebut. Hasil pengujian korelasi Spearmen didapatkan nilai koefisien korelasi sebesar -0,074 yang berarti hubungannya sangat lemah, dan nilai signifikansi yang diperoleh yaitu 0,601 yang mana nilai signifikansi lebih besar dari 0,05 yang menunjukkan bahwa tidak terdapat korelasi antara IMT dengan kecepatan aliran darah.

\section{KESIMPULAN}

Berdasarkan hasil Uji Statistik hubungan kecepatan aliran darah pada arteri abdominalis terhadap indeks massa tubuh dapat disimpulkan bahwa tidak terdapat korelasi antara IMT dengan kecepatan aliran darah. Adapun distribusi nilai kecepatan aliran darah berdasarkan IMT didominasi oleh kategori kecepatan lambat dengan persentasi masing-masing untuk kurus $23,077 \%$, normal $19,231 \%$, gemuk $25,000 \%$ dan obesitas $23,077 \%$.

\section{UCAPAN TERIMAKASIH}

Ucapan terimakasih deberikan kepada Direktur RSU Anutapura yang telah memberikan izin untuk peneliti melakukan penelitian beserta dr. Dafriana Sp. Rad yang telah membantu proses pengambilan data pasien.

\section{DAFTAR PUSTAKA}

Anggraini, dkk (2009). Faktor-faktor yang Berhubungan dengan Kejadian Hipertensi pada Pasien yang Berobat di Poliklinik Dewasa Puskesmas
Bangkinang Periode Januari sampai Juni 2008 [internet]. c2009 [cited 2011 Oct 7]. Available from: http://yayanakhyar.files.wordpress.com

Ganong, WF. (2008). Buku Ajar Fisiologi Kedokteran. Jakarta. EGC.

Hardiyan L.F, (2013). Analisis kecepatan Darah Pada Arteri Karotis Bagi Pasien Hipertensi Dengan Menggunakan Color Doppler Sonografi. Fisika FMIPA, UNMUL, Samarinda.

Kemenkes,2013.Available:http://www.depkes .go.id/resources/download/general/Hasil \%20Riskesdas\%202013. pdf diakses tanggal 2 Januari 2015.

Sugondo, S. (2009). Obesitas, In: Sudoyo, AW., Setiyohadi, B., Alwi, I., Simadibrata, M., Setiati, S., editor. Buku Ajar Ilmu Penyakit Dalam Jilid III. Jakarta: Penerbit Departemen Ilmu Penyakit Dalam FK UI

Palmer. P.E.S. (2002). Panduan Pemeriksaan Diagnostik USG.

Pearce C, Evelyn. (2008). Anatomi dan Fisiologi untuk Paramedis. PT. Gramedia Pustaka Utama: Jakarta.

Samad, S. (2012). Analisis kecepatan Darah Pada Aorta Abdominalis Bagi Pasien Hipertensi Dengan Mengunakan Color Doppler Sonografi. Fisika FMIPA, UNHAS. Makassar. 